\title{
Factors Affecting Maize Productivity of Credit Owner Farmers of Zarai Taraqiathi Bank Limited in Rural Area of District Mardan-Pakistan
}

\author{
Dr.Naushad Khan \\ Assistant Professor, Institute of Development Studies, The University of Agriculture Peshawar
}

\begin{abstract}
Maize is the staple food of District Mardan and majority people used for their livestock as a fodder. The major objective of the study was, to analyze the factors, which affect maize production of ZTBL Credit Owner Farmers, in District Mardan. It consists of three tehsil namely Mardan, Katlang and Thakhth Bai. Total 226 credit owner farmers of the ZTBL were selected for the study and data were collected with the help of interview schedule from the respondents and used Cob Douglass Production Function and Quintile Regression Function for analysis. According to finding Un-standardized coefficients of the constant is 1.501 and found significant at .05 level, while land, plough, seeds, fertilizer, weedicides, labor days, irrigation and credit coefficients were estimated $.021,-.002,0.018,0.037,0.080,0.099, .798$ and .017 respectively. The weedicides, labor days and irrigation were found significant but the remaining were found non-significant at .05 level. The land and plough relationship with Yield were found negative, while the other variables relationship were found positive with the yield, which shows that on the average, if one per cent increase in inputs of each of the land, plough, seeds, fertilizer, weedicides, labor days, irrigation and credit will be applied, then, $-0.02,-0.002,0.018,0.037,0.080,0.099,0.798$ and 0.017 percent change will be occurred respectively in the yield of maize. The model over whole was found significant. The model is considered best fit and indicates $83 \%$ explanatory variation in the model. The total output elasticity was estimated 1.026, which shows increasing return scale of the model and shows that when one unit input of the all variables were applied for output gaining, then 1.026 units output will be produced by these inputs, which indicates that the output is greater than the input and shows the increasing return scale. According to Nonparametric Quintile Regression the constant value coefficient was 6.57, while land, plough, seeds, fertilizer, pesticides, labor days, irrigation and credit coefficients were found -.017, .008, ,.031,-..032,- .036, .891 and -.002 respectively. Only seeds and irrigation coefficients were found significant at .05 level, while the remaining variables coefficients were found non-significant in the finding. In this model land, fertilizer and credit relation was found negative, while the remaining were found positive. The main reason is the low credit facility to the farmers to solve the problems of all inputs. The $\mathrm{R}^{2}$ value was found 0.335 , which explain $33.5 \%$ variation in the model. The model is not considered good fit, because it is below $60 \%$ level. The value of total elasticity of output was 0.89 , which shows decreasing return in scale. If one percent investment increase occurs in the inputs of all the variables then 0.89 percent change will be occurred in the total productivity of the maize in the study area. In some cases the relation between the inputs and output is negative and non significant while in the real sense it is not possible however some climatic factors also affect the production negatively which affect the output negatively. There the output value is less than the input values and the return is considered in decreasing return. On the basis of finding the study concludes that without these factor applications, the high productivity of maize is impossible while the study area farmers are very poor, so they do not afford the cost of the inputs, so it is recommended that all factors play key role in the enhancement of maize productivity and the study analyzed that credit availability to farmer is less than the requirement of the farmers which instead of benefits give the loss to the farmers and latter on the farmers not capable to return the said loan to the bank in time and sell land for payment to the bank, so it is recommended that government should increase the credit facility on low interest rate according to farmers requirement while also efficient monitoring system by bank is requested for enhancing maize productivity in the study area.
\end{abstract}

Keywords:-Analysis, Affecting, Credit Owner Farmers, Factors, , Maize Production, Rural Area of District Mardan

DOI: $10.7176 / \mathrm{JESD} / 10-5-07$

Publication date:March $31^{\text {st }} 2019$

\section{INTRODUCTION}

Agriculture means the biologic growth through scientific and artifice ways on the farms. Pakistan is an agriculture country and majority population based on agriculture. It is still the largest sector of Pakistan economy. Its contribution in GDP is 21.4 percent and employments share in labor force is 45 percent while in export is $70 \%$. Agriculture sector consists of sub sectors which include crops, vegetables, fruits, livestock's, fisheries and forestry. The crop sub sector is further divided into important crops, other crops, cotton and ginning. The important crops account for 25.24 percent of agricultural value added and registered a growth of 2.3 percent 
compared to a growth of 7.6 percent last year. The important crops including, maize, wheat, rice, sugarcane and cotton witnessed growth in production of 6.7 percent, 3.23 percent, 10.05 percent, 6.98 percent and -4.19 percent respectively (GOP, 2012-13).

Maize (Zea mays L.) is a multipurpose crop that supply food to human being, animals while particularly poultry, livestock and raw material to industries (Khaliq et al., 2004). It is the third cereal crop subsequent to wheat and rice while in Khyber Pakhtunkhwa $2^{\text {nd }}$ after wheat in its role. In 2010 it was cultivated on an area of 981 (000 ha) with a total production of 36581 (000 ton) in Pakistan while during the same season its area of cultivation and production in KP was 512 (000 ha) and 1468 (000 ton) respectively (FAO 2010). Green revolution caused significant increase in crop production particularly in cereal crops like wheat, maize and rice in Pakistan. However it is now shadowed by new challenges related to soil degradation such as erosion, decline of soil organic matter content, problems caused continuous application of organic fertilizer and ever escalating price of chemical fertilizers (Farhad et al., 2009). Increasing yield and decreasing production cost as well as to maintain soil health is newly emerging challenge for agricultural scientists while finance is also a great problems for all farming activities in the country.

Cocu and Amegnalgo (2018) told that increased agricultural productivity is the primary aim of all agricultural policies undertaken in developing countries. Increased agricultural productivity involves not only the analysis of factors limiting productivity but also efficiency because improved efficiency leads to productivity improvement. This paper investigated the factors limiting maize productivity in Benin based on a survey of 354 maize farmers. The mean maize yield was $1,347 \mathrm{~kg} / \mathrm{ha}$. The low level of maize yield in Benin is due to the lack of access to inputs, capital, and the weak institutional environment in which farmers operate. Furthermore, the efficiency model revealed that an increase in maize output of about 25 percent can be achieved in the short run by adopting the best farming practices and by addressing socio-economic and structural constraints. Policy should be encouraged that would facilitate access to inputs, capital, and training, and promote the development of infrastructure in farming areas.

Maize (Zea mays), also called corn, is believed to have originated in central Mexico 7000 years ago from a wild grass, and Native Americans transformed maize into a better source of food. Maize contains approximately $72 \%$ starch, $10 \%$ protein, and 4\% fat, supplying an energy density of $365 \mathrm{Kcal} / 100 \mathrm{~g}$ and is grown throughout the world, with the United States, China, and Brazil being the top three maize-producing countries in the world, producing approximately 563 of the 717 million metric tons/year. Maize can be processed into a variety of food and industrial products, including starch, sweeteners, oil, beverages, glue, industrial alcohol, and fuel ethanol. In the last 10 years, the use of maize for fuel production significantly increased, accounting for approximately $40 \%$ of the maize production in the United States. As the ethanol industry absorbs a larger share of the maize crop, higher prices for maize will intensify demand competition and could affect maize prices for animal and human consumption. Low production costs, along with the high consumption of maize flour and cornmeal, especially where micronutrient deficiencies are common public health problems, make this food staple an ideal food vehicle for fortification.

Native to the New World, today corn is a staple food for a large part of the population around the globe, being especially important to the diets of several African countries. Corn can be consumed in a variety of ways, including, but not limited to, as porridge (such as grits, polenta, or ugali), a popcorn, roasted or fired kernels, as a vegetable (in the form of fresh, frozen, or canned sweet corn), or as flour or meal (cornbread, tortillas, chips, extruded snacks, etc.). Corn is also used to make ethanol (for either drinking or as a fuel source for motor vehicles), its by-products and grains as animal feed and biomass for energy, as a source of cooking oil, and for corn syrup and corn starch in the food industry. Nonetheless, and despite it global reach, 4 of the top 10 cornproducing countries today are still to be found in the Americas to where the crop is native. The crop especially proliferates in the Midwestern Region of the United States, from where some of the world's greatest yields are sourced. South Africa was the 10th largest corn producing country in the world in 2014, producing 15.5 million metric tons of corn in the same year. The crop is cultivated primarily in the north and north-eastern regions of the country. The South African provinces of Guateng, North-West, Mpumalanga, and Orange Free generate the highest yields of corn in the country. The grain is planted between the months of September to December and harvested between April and June. In France, corn is grown throughout the country, though the southern part of the nation is responsible for majority of the production. $21 \%$ of the total corn produced in the country is obtained from the Aquitaine region, and $13 \%$ is contributed by the French state of Midi-Pyrenees. The crop is generally planted in the country between April and May, and harvested between September and November. France produces around 17.1 million metric tons of corn per year as per the data obtained from FAOSTAT's estimates for 2014. Due to its heavy production levels and low consumption levels, much of the corn produced in the country is exported, rendering France the third largest corn exporter in the world. Indonesia is the leading corn producer among the members of the ASEAN Economic Community, with the Philippines and Vietnam trailing behind. In 2014, Indonesia produced 19 million metric tons of this grain, which was slightly higher than the 18.5 million metric tons produced in 2013. Despite being a large corn producer, this Southeast Asian country 
consumes more corn that it produces. Though the country produced 18.5 million metric tons of corn in 2013 , it consumed 20.8 million metric tons in the same year. The majority of the corn is consumed by Indonesia's booming livestock sector. Key to increasing corn output in this country would be the acquirement of land upon which to expand its corn plantations, though this might unfortunately mean encroachment into forested lands and the destruction of wild, native vegetation. Corn is the most important crop grown in Mexico, with almost $60 \%$ of the country's cropland being dedicated to this agricultural commodity. The central portions of Mexico contribute nearly $60 \%$ of the total corn produced in Mexico. The country harvests two corn crops per year. Within these, the main crop accounts for $70 \%$ of the annual corn production, and the secondary harvest makes up the remaining $30 \%$ of the total corn production of the country. As per the FAOSTAT data from 2014, corn production in the country was 32.6 million metric tons in 2014, which was significantly higher than the 2013 production level of 22.4 million metric tons. Though the corn produced in the country is self-sufficient to meet the human consumption within the country, and a large part of the produce is also dedicated as animal feed, Mexico still needs to import feed corn for its rapidly growing livestock sector. The Ukraine, along with Russia and Kazakhstan, lists among the three principal players responsible for corn production in the Black Sea region. The Ukraine has vast stretches of fertile land richly endowed with CHERNOZEM (or 'black soil'), and this chernozem is some of the most fertile soil in the world. Thus, despite being a small country, a wide variety of crops grow here in abundance. Ukrainian growers produce 39.2 million metric tons of corn annually. In 2013 , $46 \%$ of Ukraine's corn was exported to other markets in the European Union. Meanwhile, 14\% of the corn was exported to Egypt and an 11\% share of the maize production was delivered to markets in South Korea. The other important markets for Ukrainian corn are to be found in Japan, Iran, China, Syria, and a few more countries. $16 \%$ of the world's corn export totals are contributed by the Ukraine.

The corn production in Argentina is currently estimated to be around 40 million metric tons, as per the 2014 estimates by FAOSTAT. According to recent reports generated by the Agriculture Ministry of the country, the farmers of Argentina planted around 5.88 million hectares of corn in the 2015-2016 session. The corn acreage in Argentina in the 2015-2016 period, measured by the Buenos Aires Grains Exchange, was estimated to be significantly less, at around 2.72 million hectares. The recent change in the country's government administration also provided a boost to the country's corn producers. India produces 42.3 million metric tons of corn annually, as per the estimates of the 2014 FAOSTAT data. The crop is primarily grown in the northern states of the country, including Uttar Pradesh, Bihar, Himachal Pradesh, Rajasthan, and a few others. Uttar Pradesh is the largest corn producing state in the country, accounting for nearly $16 \%$ of the country's corn production. Bihar ranks second in corn production, and produces nearly $14 \%$ of the corn in the country. The crop is usually planted at the beginning of the rainy season, between mid-May and July, and is harvested between the first week of November through the end of January. Full season corn planting in Brazil begins in August and lasts into October or November. The SAFRINHAcrop, treated as a secondary crop and usually rotated with soybeans to maximize soil nitrogen levels, is planted at a later stage, in the months from January through February, and sometimes as late as March. The country is the third highest corn producer in the world, producing nearly 83 million metric tons of this crop annually. The peak monthly corn export statistics of the country exhibit a substantial increase as of late, from 1.10 million metric tons in February of 2015 to 5.37 million metric tons in February of 2016. The increased export volume also led to an increase in revenue from \$206.4 million in February of 2015 to $\$ 892.2$ million in February of 2016 . Though rice has long served as the staple food for the Chinese population, over the past few years corn has increasingly replaced rice in its bid to become the top crop in the country. The reason for this change is not attributed to a change in dietary patterns of the Chinese people themselves, but rather to the increasing demand for livestock feed in the country. Over the past 25 years, corn production has undergone a significant increase of $125 \%$, while the rice production has undergone only a $7 \%$ increase in the country within the same time span. As a greater volume of the Chinese population is moving towards urban areas, and as wealth and Western tastes increase as well, the consumption of meat in the country is continuously increasing, and so is the need for livestock feed. While in the 1940s two-thirds of the Chinese corn crop production was used for human consumption, currently $60 \%$ is used as animal feed. $10 \%$ of the corn is used for direct human consumption, and the remaining 30\% is used in industrial production to produce such products as corn-based alcohols, sweeteners, and cooking oils. With the USA producing nearly 377.5 million metric tons of corn, the crop definitely plays a very significant role in the country's economy. The United States is the worldwide leader in corn production, and $20 \%$ of its annual corn production is exported. 96,000,000 acres of land in the USA are dedicated to corn production. The crop was first introduced into the country thousands of years ago along what is now the US-Mexico border, with the original crop being referred to as "teosinte" in Mexico. After that time, many Native American groups as far north as Canada adopted corn as a staple crop, around which to base more stationary, subsistence agriculture-dependent lifestyles. The practice of corn cultivation was soon learned by the immigrants settling in the Western United States from the Native Americans in the region, and corn cultivation quickly spread across the country's non-Native American farming population. Currently, a large number of US states produce corn, with Iowa being the largest producer of the crop in the 
country. Iowa led the country in corn production in 2015, closely followed by Illinois and Nebraska. Iowa and Illinois each produced about 2 billion bushels of this crop in 2015. Minnesota and Indiana, meanwhile, each produced over 1 billion bushels of corn in the same year(https:/www.worldatlas.com/articles/world-leaders-incorn-maize-production-by-country.html)

According to (FAO) Statistics, 2007 world total area under maize crop was 157874 thousand hectares and total production was 784787 thousand $\mathrm{Kg}$ while per hectare production was $4971 \mathrm{Kg}$. The per hectare top production in the world was the USA which was $9482 \mathrm{Kg}$ while the lowest per hectare production was the Romania which was $1740 \mathrm{Kg}$. The India production per hectare was $2160 \mathrm{Kg}$, however the Pakistan per hectare production was $3240 \mathrm{Kg}$. According to Agricultural Statistics of Pakistan (2010-11) in 2002-03 the total area under maize in Pakistan was 935.5 thousand hectares while in 2010-11 was 965.2thousands hectares and percent change was 3\%, in 2002-03 in Punjab was 419.5thousand hectares and in 2010-11 was 534.6thousand hectares, so change was 27\% , in 2002-03 in Sindh was 6.7thousand hectares while in 2010-11 was 2.5thousand hectares, so the change was $-63 \%$. However the total area under maize in 2002-03 in KP was 506.4thousand hectare while 2010-11 was 422.9thousand hectares, so the change was-16\%, in 2002-03 the total area under maize in Baluchistan was 2.9thousand and in 2010-11 were 5.2thousands hectares, so the change was 79\%. The highest changes in area occurred in Baluchistan Province followed by Punjab province. The highest negative change occurred in Sindh Province followed by KP. However in 2002-03 the per hectare production in Pakistan was $1857 \mathrm{Kg}$ while $2010-11$ was $3805 \mathrm{Kg}$, so the change is $105 \%$. In Punjab the per hectare production in $2002-03$ was $2105 \mathrm{Kg}$ while in $2010-11$ the per hectare production was $5444 \mathrm{Kg}$, so percent change is $159 \%$. In Sindh the per hectare production in $2002-03$ was $537 \mathrm{Kg}$ while in $2010-11$ the per hectare production was $640 \mathrm{Kg}$, so percent change is $19 \%$. However in 2002-03 the per hectare production in KP was $1676 \mathrm{Kg}$ while in $2010-11$ the per hectare production was $1751 \mathrm{Kg}$, so the percent change is $5 \%$. In 2002-03 the per hectare production in Baluchistan was $1069 \mathrm{Kg}$ while in $2010-11$ the per hectare production was $1096 \mathrm{Kg}$, so the percent change is $3 \%$. All the way positive changes occurred in all the province in per hectare production while highest changes occurred in the province of Punjab followed by Sindh. The smallest change was observed in Baluchistan province. The Agricultural finance is an important financial support to farmers for fulfilling their financial requirements for farm activities which fill the gap between their income and expenditure in farming operation. Farming not only requires finance for quality seeds, fertilizer and modern equipments but also requires liquid capital for other activities of the farm (Iqbal et.al, 2003). In Pakistan, there are two type of credit, formal and non formal. Formal credit is institutional credit which provided to farmer by institution such as ZariTarkiati Bank Limited (ZTBL), commercial banks, cooperatives and domestic private banks while non formal credit is the noninstitutional credit which links with friends, neighbors, and professional money lenders in the country (Idress and Ibrahim, 1993).

Table 1 indicates the maize area and production in Khyber Pukhthun Khawa 2007-2009. The total area of Khyber Pukhhun Khawa in 2007-08 was 509 thousand hectares and the production was 813.2 thousand tons while in 2008-09 the total area was 509.4 thousand hectares and the production was 928.3 thousand tons. Area wise the district swat was on the top followed by Mansehra and Buner in 2007-08 while in 2008-09 was also Swat was on top and followed by Mansehra and Bunir. Production wise in 2007-08 Mansehra was on top and followed by Swat and Mardan. In 2008-09 in Production Mansehra was on the top and was followed by Mardan and Swat. The total area of Mardan in 2007-08 was 31 thousand hectares and in 2008-09 the area was 32.3 thousand hectares while in 2007-08 the production was 96.6 thousand tons while in 2008-09 the production was 110.5 thousand tons. The table further shows the lowest area and production in Karak and Tank So the table show that Mardan district play great role in the production of maize crop in the whole province of Khyber Pukhthun Khwa and it also indicates that this district area is favorable for maize production (http://www.amis.pk/Agristatistics/DistrictWise/Maize.html). 
Table 1 Maize Aea And Production In Khyber Pukhthun Khwa (Hectares And Tons)

\begin{tabular}{|c|c|c|c|c|c|}
\hline \multirow{2}{*}{ Sr.No } & \multirow{2}{*}{ Name of District } & \multicolumn{2}{|c|}{ Area (Area in '000' Hectares) } & \multicolumn{2}{|c|}{ Production (Production in '000'Tonnes) } \\
\hline & & 2007-08 & 2008-09 & 2007-08 & 2008-09 \\
\hline 1 & Peshawar & 16.6 & 16.9 & 29.3 & 29.8 \\
\hline 2 & Charsadda & 17.4 & 16.2 & 40.3 & 56.5 \\
\hline 3 & Nowshera & 10.9 & 10.9 & 24.6 & 31.0 \\
\hline 4 & Mardan & 31.0 & 32.3 & 96.6 & 110.5 \\
\hline 5 & Swabi & 32.7 & 32.8 & 71.5 & 71.2 \\
\hline 6 & Kohat & 2.2 & 2.1 & 3.1 & 3.1 \\
\hline 7 & Hangu & 8.1 & 6.9 & 8.4 & 7.2 \\
\hline 8 & Karak & 0.0 & 0.1 & 0.1 & 0.1 \\
\hline 9 & Mansehra & 60.1 & 59.1 & 106.3 & 127.9 \\
\hline 10 & Battagram & 16.1 & 20.0 & 20.0 & 29.2 \\
\hline 11 & Abbottabad & 14.3 & 14.3 & 21.6 & 22.1 \\
\hline 12 & Haripur & 39.6 & 39.3 & 47.6 & 51.1 \\
\hline 13 & Kohistan & 26.6 & 26.7 & 52.2 & 53.3 \\
\hline 14 & Malakand & 5.5 & 5.5 & 11.1 & 11.7 \\
\hline 15 & Swat & 62.3 & 62.4 & 104.8 & 101.5 \\
\hline 16 & Bunir & 52.4 & 48.1 & 75.5 & 72.2 \\
\hline 17 & Shangla & 37.0 & 37.6 & 62.6 & 63.7 \\
\hline 18 & Dir Lower & 9.3 & 9.3 & 13.5 & 14.0 \\
\hline 19 & Dir Upper & 7.3 & 7.3 & 17.2 & 11.3 \\
\hline 20 & Chitral & 5.7 & 5.7 & 13.1 & 13.1 \\
\hline 21 & D.I.Khan & 1.2 & 1.1 & 2.8 & 2.5 \\
\hline 22 & Tank & 0.1 & 0.1 & 0.2 & 0.2 \\
\hline 23 & Bannu & 4.9 & 4.0 & 8.9 & 7.3 \\
\hline 24 & Lakki Marwat & 0.6 & 0.8 & 1.1 & 1.5 \\
\hline 25 & Mohmand Agency & 2.7 & 2.8 & 4.1 & 4.2 \\
\hline 26 & Khyber & 3.0 & 3.3 & 5.0 & 5.7 \\
\hline 27 & Kurram & 1.9 & 2.2 & 3.2 & 2.7 \\
\hline 28 & Orakzai & 4.1 & 4.2 & 4.4 & 4.4 \\
\hline 29 & Bajour & 17.7 & 20.2 & 27.4 & 21.8 \\
\hline 30 & N.W & 6.4 & 6.4 & 9.7 & 9.8 \\
\hline 31 & S.W & 6.6 & 6.7 & 10.4 & 10.4 \\
\hline 32 & F.R. Peshawar & 2.0 & 1.9 & 3.1 & 2.9 \\
\hline 33 & F.R. Kohat & 1.3 & 1.3 & 1.9 & 1.8 \\
\hline 34 & F.R. Bannu & 0.8 & 0.8 & 1.3 & 1.4 \\
\hline 35 & F.R. D. I. Khan & 0.6 & 0.6 & 1.0 & 1.0 \\
\hline & Total & 509 & 509.4 & 813.2 & 928.3 \\
\hline
\end{tabular}

Government of Pakistan attaches high priority to ensure the timely availability of finance to the farmers for achieving higher production. Finance requirements of the farming community have shown an increasing trend over the years. Therefore, agricultural finance was increased by the government from Rs.42852. Millions to Rs.215965.34 millions during 1998-2011 while in 2011-2012 it decreased 66\% due to unavoidable situation in the country. Institutional finance to the farmers is being provided through ZTBL, Commercial Banks, Cooperatives and Domestic Private (Banks. Economic Survey (2011-12) Economic Affairs Finance Division, Islamabad). Access of small and marginal farmers to micro finance can significantly help them to avoid sliding down the poverty ladder. Providers of the micro finance have not generally addressed the credit need of the small and marginal farmers because of their priority of funding to the poor and some other problems which include (a) risk of invest in agriculture; (b) Seasonality of agricultural production; (c) poor loan repayments, performance of agriculture lending; and (d) technical nature of an agriculture production system. As far the institutional finance is concerned, the small and landless farmers find it very difficult to avail it due to lack of availability of collateral and complex procedure to be followed. There is, therefore, a dire need to start a finance program to benefit the maximum number of poor communities without any complicated collateral system (Ahmad, 2007). There are many factors which affect the production of maize in the study area. Among these quality of land, water availability, fertilizer availability, seed quality, Modern machinery, credit availability by bank, markets 
availability and skills etc are the factors which affect the production of maize in the study area. Seeing to its importance the cited title study was selected.The major objective was to analyze the factors which affect the productivity of maize of credit owner farmer of ZTBL in the study area.

\section{Review of Literature}

Khan and Jan (2012) studied that in Pakistan number of initiatives in the recent past was started to provide financial assistance to farmers, to improve the farm productivity and socio-economic condition of the farmers. One of these initiatives is the emergence of the micro- finance Khushali bank in the country. The study was conducted to examine the effects of Khushali Bank Limited finance program on agricultural productivity and problems/constraints faced to farmer in the study area. The result of the study revealed that the availability of finances by bank showed a significant increase in the production of crops such as wheat, maize, sugarcane, tobacco, poplar while Such type activities also increased 16\% income of the respondents in the project area. The less amount availability and high interest rate was found a barrier to farmer in taking loan from the bank. The respondents considered the amount Rs. 12880 to each one by bank non sufficient for their field requirement. During survey it was also recorded that the interest rate was higher for uplifting their economic condition. The result also revealed that the outskirt farmer of the villages could not benefit

Cocu and Amegnalgo (2018) examined the determinants of maize farmers' performance in Benin based on a sample of 354 farmers across the three main climatic zones in Benin. The results revealed that the mean maize yield in Benin was around 1,347 kg/ha. The increase in maize yield in Benin requires production intensification (capital, fertilizer, labor, and seed) rather than increased land area. Improvement of access to extension services and markets would also contribute to yield improvement.Another avenue for yield increase is improved farmer efficiency. The results indicated that there was significant variation in technical efficiency among maize farmers, as the estimated efficiency ranged from 0.22 to about 0.94 with mean technical efficiency levels of 75 percent. This indicates that maize production could be increased by 25 percent through better use of available resources such as land, labor, seed, and fertilizer given the state of technology. Farmers were operating at an increasing return to scale. Male maize farmers who had not had a formal education, with lower farming experience, and a smaller household size, but with relatively good access to markets, extension services, and the use fertilizer achieved higher levels of technical efficiency in maize production in Benin.

Justin( 2015) told that production of staple food occupies an important part in Sub-Saharan Africa's agricultural production. Maize crop in particular is the most important staple food in this area. The article mainly examines households' socio-economic characteristics affecting maize production in Rukwa in the context of the market reforms carried out in Tanzania in the mid 1980's. Rukwa region is one of Tanzania's most reliant maize producers. The article explores the importance of maize to household's crop production, its production levels and the determinants of its productivity. A number of specific issues are explored including the importance of factors such as farm size, education, and access to key inputs such as seeds, fertilizers and agricultural extension services. The study on which the article is based uses data collected from three districts of Rukwa. The findingsshowed that maize crop continues to play an important role in most households' livelihood. However, the crop production levels were low. Education was observed to be an important factor in raising yields, suggesting that non-agriculture policies may also be important for improving productivity and welfare of farmers. Despite the importance of maize crop to household livelihoods, several constraints were reported to hinder its productivity including access to fertilizers, improved seeds and other chemical inputs necessary for higher production, and extension services. Therefore, efforts need to be taken by both the local and central government to raise households maize productivity and hence increase the possibility of improving their well-being.

The purpose for this study was to investigate factors influencing maize production among small scale farmers of Bungoma Central Sub County, Kenya. The study was guided by the following objectives: to investigate how costs of production influence maize production of small scale farmers, to establish how demographic characteristics influence maize production of small scale farmers, to determine how extension services influence maize production of small scale farmers and to examine how accessibility to credit influence maize production of small scale farmers of Bungoma Central Sub County. The study adopted descriptive survey design which was used to obtain information to describe the existing phenomena. The target population was 18,580 both male and female consisting of small scale farmers. The estimated sample size was 202 from the target population using Cochran 1963 formula at 7\% level significance. The study employed stratified random sampling in order to include all the wards; proportionate allocation was used to determine the number of farmers from each ward that would be the respondents in the study. Systemic random sampling was used to select the actual respondents from the wards. Content validity was used where the researcher shared the research instrument with his supervisors to assess its appropriateness in content. Split half method was employed to test the reliability of the instrument. A questionnaire with closed ended questions was prepared and distributed to the respondents in all the wards. The questionnaires were then collected after one week. All the questionnaires were filled and were used for analysis. Data was analyzed using descriptive method. Frequency tables and percentages 
were used for data presentation after analysis. The findings revealed that fertilizer remains the most costly input in maize production, followed by land preparation. Also most farmers do not attend field days and only a negligible percentage have access to credit. The national and county governments should avail subsidized fertilizer in good time and make it easily accessible. Proper sensitization should be done by agricultural extension officers to all farmers about the available extension services and county government should provide sufficient facilitation to agricultural extension officers to promote extension services. Farmers should be encouraged to form groups in order to access credit services, market their produce and acquire farm inputs collectively. Both national, county governments and financial institutions should make credit easily accessible and affordable to small scale farmers. The researcher recommends further research on causes of low attendance of field days and low level of accessing extension services in general to ascertain the underlying causes of low dissemination extension(information(http://erepository.uonbi.ac.ke/bitstream/handle/11295/74143/Simiyu Factors\%20influenc ing $\% 20$ maize $\% 20$ production $\% 20$ among $\% 20$ small $\% 20$ scale $\% 20$ Farmers $\% 20$ in $\% 20$ Kenya.pdf? sequence $=1$ ).

Braimoh and Vlek (2006) studied that food security is a crucial issue in sub-Saharan Africa as a consequence of unreliable rainfall, marginal soil fertility and a low level of inputs leading to declining crop yields. As a case study, we investigated the most important variables affecting maize yield in northern Ghana. We combined a soil quality index on a continuous scale with a social data set to model maize yield using linear multiple regression. Five significant variables have been identified $\left(\begin{array}{l}P<0.05\end{array}\right)$ : soil quality index, fertilizer use, household size, distance from main market, and the interaction between fallow length and soil quality index. The effect of the interaction between soil quality and fallow on maize yield is negative, suggesting the influence of litter quality and $\mathrm{N}$ immobilization in the soils. Research and policy should focus on the development of site-specific, legume-based cropping, and the integration of crop and livestock farming in Northern Ghana and similar areas in sub-Saharan Africa.

Agriculture plays an important role in raising the economy of Rwanda. Maize is one of the dominant crops that has a good productivity in the study area. An efficient use of the existing resources by farm households improves their productivity and thereby increases their output. Most researches on agriculture focused on how to achieve certain level of yield. However, few researches consider rational resource allocation to improve productivity efficiency. The main objective of the study was to conduct an economics analysis of the factors influencing maize productivity and efficiency among farmers in Rwanda. The first specific objective of this study was to determine the production factors influencing maize productivity in study area, the second objective was to find out socio-economic and institutional factors influencing technical, allocative, and economic efficiency among maize farms in study area.This study was based on the cross-sectional data collected in July 2015. A multi-stage sampling procedure was applied to the population of maize farmers from the area under study and 168 respondents were proportionally selected from seven zones of farming. A Stochastic production frontier model was used to estimate technical, allocative and economic efficiency levels, whereas Tobit model was used to identify factors affecting efficiency levels. The result showed that the maximum yield of maize is $4800 \mathrm{~kg} / \mathrm{ha}$. The average values for seeds and chemical fertilizer inputs ranges between 10-21.4 and 20-67 kg per hectare, respectively. The maximum organic manure used was of $10000 \mathrm{~kg} / \mathrm{ha}$. The average value for pesticide used was 1.54 litter /ha. The average figure for labor is 178 person-days per hectare. The study result indicated that the mean technical, allocative, and economic efficiency score for the sampled farms were 51.78\%, 63.17\%, and $54.17 \%$ respectively. It was found that improved seeds, land size, organic manure, labor and chemical fertilizer positively and significantly influenced maize productivity. Factors such as access to credit; extension services, work experience in maize production; and family income were found to be statistically significant at $1 \%$ level on the influence of the technical efficiency in the study area. However, household head age and distance to market showed a negative and significant effect on technical, allocative and economic efficiency of the maize farms. Thus, government agencies especially Rwanda Agriculture Board and local government and researchers should take into consideration the above indicated production, socio-economic and institutional factors to improve productivity of maize in the study area.(http://ir.jkuat.ac.ke/bitstream/handle/123456789/3480/Ntabakirabose-

2C\%20Gaspard\%20Agricultural\%20and\%20Applied\%20Economics-

2017\%20mirror1.pdf? sequence $=1 \&$ isAllowed $=y$ )

Scheiterle and Birne (2010) Studied that Maize is one of the most important crops produced and consumed in Ghana, accounting for $58 \%$ of local cereal production. Increasing food prices worldwide and the gap between production and consumption of maize in recent years in Ghana present the country with growing import bills and higher prices for consumers. The purpose of this study was to analyze whether farmers in the northern sector of Ghana have a comparative advantage in the production of maize as import substitution. The effect impact of the fertilizer subsidy program on the yield itself and consequently on the private and social profitability has been tested. Fertilizer subsidy programs are one of the most popular policy programs in Africa. In the mid90s many countries introduced them to increase crops yield. Household survey data of the cropping season 2010 were 
collected and complemented with data from different institutions. We applied the Policy Analysis Matrix (PAM), to assess policy effects on production systems, and the Cobb-Douglas production function to identify factors affecting the output of each system. The results suggest that production systems with yields above the national average of $1.5 \mathrm{Mt} / \mathrm{ha}$ are profitable at private level and contribute to growth of the national economy. Farming systems producing below this threshold report negative social profits, implying that they do not use scarce resources efficiently in the production of maize and depend on government intervention. Policy implications are drown and, in conclusion, we consider essential to combine single policy tools and used in synergy to realize the full efficiency of each.

Ranum et. al (2014) Studied that Maize (Zea mays), also called corn, is believed to have originated in central Mexico 7000 years ago from a wild grass, and Native Americans transformed maize into a better source of food. Maize contains approximately $72 \%$ starch, $10 \%$ protein, and $4 \%$ fat, supplying an energy density of 365 $\mathrm{Kcal} / 100 \mathrm{~g}$ and is grown throughout the world, with the United States, China, and Brazil being the top three maize-producing countries in the world, producing approximately 563 of the 717 million metric tons/year. Maize can be processed into a variety of food and industrial products, including starch, sweeteners, oil, beverages, glue, industrial alcohol, and fuel ethanol. In the last 10 years, the use of maize for fuel production significantly increased, accounting for approximately $40 \%$ of the maize production in the United States. As the ethanol industry absorbs a larger share of the maize crop, higher prices for maize will intensify demand competition and could affect maize prices for animal and human consumption. Low production costs, along with the high consumption of maize flour and cornmeal, especially where micronutrient deficiencies are common public health problems, make this food staple an ideal food vehicle for fortification.

\section{MATERIAL AND METHODS}

The Universe of the study is District Mardan which consists of three tehsil namely Mardan, Katlang and Thakhth Bai. Total 226 beneficiaries of the ZTBL were selected from 260 ZTBL credit owners for the study and data were collected with the help of interview schedule from the respondents and used Cob Duglass Production Function and Quintile Regression Function for analysis. Diagnostic test for assumption (Normality, Multicolinearity and Heterodoscity) checking was also applied to know either it fulfill the assumptions for Cob Douglass Production function or not. Cob Douglass Production Function is the Parametric Model while Quintile Regression is the Non Parametric Model when the assumptions failure happened then the Quintile Regression is the alternative test which is applied at that occasion.

The equation is given below:-

$\mathrm{y}_{\mathrm{i}}=$ Per Hectare Maize Yield (kgs),$\beta=$ Constant, $\mathrm{X}_{1}=$ Land, $\mathrm{X}_{2}=$ Plough, $\mathrm{X}_{3}=$ Seed, $\mathrm{X}_{4}=$ Fertilizer, $\mathrm{X}_{5}=$ Weedicides, $\mathrm{X}_{6}=$ Labor days, $\mathrm{X}_{7}=$ Irrigation, $\mathrm{X}_{8}=$ Credit, $\beta_{1} \ldots \beta_{8}=$ Coefficients, $\mu_{\mathrm{i}}=$ error term

$\ln y_{\mathrm{i}}=\ln \beta+\beta_{1} \ln \mathrm{X}_{1}+\ln \beta_{2} \mathrm{X}_{2}+\ln \beta_{3} \mathrm{X}_{3}+\ln \beta_{4} \mathrm{X}_{4}+\ln \beta_{5} \mathrm{X}_{5}+\ln \beta_{6} \mathrm{X}_{6}+\ln \beta_{7} \mathrm{X}_{7}+\ln \beta_{8} \mathrm{X}_{8}+\mu_{\mathrm{i}}$.

\section{RESULTS AND DISCUSSION}

The data normality was checked, through Shapero and Kalmagro normality test. The dependent variable normality was found approximately normal but the independents variables normality was not found normal. Through VIF test multicollinreaty was checked, only the irrigation variable VIF was found higher than 5, but other variables VIF were found less than 5. So, only in one variable the multicollineaty problem was found. The problem of heterodoscity was tested through scatter plots and found the problem positive. Due to these problems, parametric and non parametric both models were applied, to fully analyze the results of the models and see the difference in both models. In such cases the non-parametric model result is considered better than parametric model due to assumption failure. As a parametric model, the Cob Douglass production function type regression in natural logarithmic form was applied; while as non-parametric model Quintile regression in natural logarithmic form was also applied. The results are given in tables 1 and 2.

Table 1 indicates Estimated Results of the Maize Crop per Hectare yield of Cob Douglass Production Function of the Respondents in the Study Area. According to the table, the Un-standardized coefficients of the constant is 1.501 and found significant at .05 level, while land, plough, seeds, fertilizer, weedicides, labor days, irrigation and credit coefficients were estimated -.021,-.002, 0.018, 0.037, 0.080, 0.099,.798 and .017 respectively. The weedicides, labor days and irrigation were found significant but the remaining was found nonsignificant at .05 level. The land and plough relationship with Yield were found negative, while the other variables relationship were found positive with the yield, which shows that on the average, if one per cent increase in inputs of each of the land, plough, seeds, fertilizer, weedicides, labor days, irrigation and credit will be applied, then, $-0.02,-0.002,0.018,0.037,0.080,0.099,0.798$ and 0.017 percent change will be occurred respectively in the yield of maize.

The $\mathrm{R}^{2}$ value was found 0.83 , which shows the model explanatory power of the model. The model is considered best fit and indicates $83 \%$ explanatory variation in the model. The F-value was 129.212 , which is highly significant at .05 level and shows overall significance of the model of the independent variable in the 
production. The total output elasticity was estimated 1.026, which shows increasing return scale of the model and shows that when one unit input of the all variables were applied for output gaining, then 1.026 units output will be produced by these inputs, which indicates that the output is greater than the input and shows the increasing return scale.

Table 1 Estimated Results of the Maize Crop per Hectare yield of Cob Douglass Production Function of the Respondents in the Study Area

\begin{tabular}{|c|c|c|c|c|}
\hline \multirow[t]{2}{*}{ Model } & \multicolumn{2}{|c|}{ Unstandardized Coefficients } & \multirow[t]{2}{*}{ t-value } & \multirow[t]{2}{*}{ Sig. } \\
\hline & $\mathrm{B}$ & Std Error & & \\
\hline $\operatorname{Constant}(\beta)$ & 1.501 & .278 & 5.395 & .000 \\
\hline $\operatorname{Land}_{(\mathrm{X} 1)}$ & -.021 & .017 & -1.234 & .219 \\
\hline Plough $_{(\mathrm{X} 2)}$ & -.002 & .035 & -.044 & .965 \\
\hline Seeds $_{(X 3)}$ & .018 & .018 & 1.015 & .311 \\
\hline Fertilizer(x4) & .037 & .038 & .972 & .332 \\
\hline Weedicides (X5) & .080 & .031 & 2.557 & .011 \\
\hline Labourdays $_{(\mathrm{X} 6)}$ & .099 & .050 & 1.984 & .049 \\
\hline Irrigation $_{(\mathrm{X} 7)}$ & .798 & .083 & 9.656 & .000 \\
\hline Credit(X8) & .017 & .018 & .973 & .332 \\
\hline
\end{tabular}

Source:- Field Survey 2012

$\mathrm{R}^{2}$ value $=0.830, \mathrm{~F}$-value $=129.212$, Total output elasticity $=1.026$

Table 2 indicates the Nonparametric Quintile Regression Coefficients of Maize per Hectare Yield in the Study Area. The constant value coefficient was 6.57, while land, plough, seeds, fertilizer, pesticides, labor days, irrigation and credit coefficients were founf-.017, .008,.031,-.032,- .036, .891 and -.002 respectively. Only seeds and irrigation coefficients were found significant at .05 level, while the remaining variables coefficients were found non-significant. In this model land, fertilizer and credit relation was found negative, while the remaining were found positive. The $\mathrm{R}^{2}$ value was found 0.335 , which explain $33.5 \%$ variation in the model. The model is not considered good fit, because it is below $60 \%$ level. The value of total elasticity of output was 0.89 , which shows decreasing return in scale. If one unit input of all the variables for output was applied, then, 0.88 unit output would be produced of the maize. There the output value is less than the input values and it is considered decreasing return scale.

Table 2 Nonparametric Quintile Regression Coefficients of Maize per Hectare Yield in the Study Area

\begin{tabular}{|c|c|c|c|c|c|}
\hline Model & $\mathrm{B}$ & Std Error & $\mathrm{T}$ & Sig & $\mathrm{R}^{2}$ \\
\hline Constant & 6.57 & .2075173 & 31.65 & .000 & \multirow[t]{9}{*}{0.335} \\
\hline $\operatorname{Land}_{(\mathrm{X} 1)}$ & -.017 & .0124497 & -1.33 & 0.18 & \\
\hline Plough $_{(\mathrm{X} 2)}$ & .008 & .0253969 & 0.31 & 0.757 & \\
\hline Seeds $_{(X 3)}$ & .031 & .0135125 & 2.33 & 0.021 & \\
\hline Fertilizer(x4) & -.032 & .0271026 & -1.17 & 0.24 & \\
\hline Weedicides(X5) & -.036 & .022756 & -1.6 & 0.110 & \\
\hline .Labourdays $(\mathrm{X6)}$ & .0345 & .0368473 & 0.93 & 0.351 & \\
\hline Irrigation $_{(\mathrm{X} 7)}$ & .891 & .0566142 & 15.73 & 0.000 & \\
\hline Credit(X8) & -.002 & .0131356 & 0.18 & 0.855 & \\
\hline
\end{tabular}

Source:- Field Survey 2012, Min sum of deviations $=44.77$, Total output elasticity $=0.89$

\section{CONCLUSION AND RECOMMENDATIONS}

The study finally concluded that the mentioned inputs play vital role in the development of maize productivity while the inputs price are so high that farmers cannot purchase inputs in time for enhancing maize productivity in study area. In first model the elasticity of output is more than the second model. The first model shows increasing return while the second model indicates the decreasing return. Both models reflect a little difference in their value and significance. The sampled farmer are facing the problems of cost of inputs and marketing of the maize product in the study area. On the basis of problems the study recommends credit facilities to farmer on low interest rate according to their requirement for enhancement of maize productivity for purchasing their inputs in the study area. Better market facilities are also required for farmers for enhancement of maize productivity and high price also play key role in the development of maize productivity in the study area.

\section{REFERENCES}

1. Ahmad, M. 2007. Evaluation of AKRSP' Micro Credit Program on Agriculture and Enterprise Development in District Astore, Northern Areas. Faculty of rural Social Sciences, M.Sc (Hons) Thesis Agric. NWFP AUP.

2. Braimoh A.K and Vlek P.L.G, 2006. Soil quality and other factors influencing maize yield in 
northern.Ghana(https://doi.org/10.1111/j.1475-2743.2006.00032.x)

https://onlinelibrary.wiley.com/doi/pdf/10.1111/j.1475-2743.2006.00032.x

3. Cocou and Amegnalgo (2018). Determinants of maize farmers' performance in Benin, West Africa. Open Access funded by Kasetsart University. https://doi.org/10.1016/j.kjss.2018.02.011

4. District Wise Area and Production of Khyber Pukhtun Khwa of Maize Crop (http://www.amis.pk/Agristatistics/DistrictWise/Maize.html).

5. Economic Survey (2011-12). Economic Affairs Finance Division, Islamabad.

5. Economic Survey (2012-13). Economic Affairs Finance Division, Islamabad.

6. Food and Agricultural (FAO) Statistics, 2007 (www.maize2007.org/FAO,2007)

7. Anonymous. FACTORS INFLUENCING MAIZE PRODUCTION AMONG SMALL SCALE FARMERS IN KENYA, A CASEOF BUNGOMA CENTRAL SUB COUNTY SILVANUS WANJALA SIMIYU A RESEARCH PROJECT SUBMITTED IN PARTIAL FULFILLMENT OF THE REQUIREMENT FOR THE AWARD OF DEGREE OF MASTERS OF ARTS IN PROJECT PLANNING AND


(http://erepository.uonbi.ac.ke/bitstream/handle/11295/74143/Simiyu_Factors\%20influencing\%20maize\%2 0production\%20among\%20small\%20scale\%20Farmers\%20in\%20Kenya.pdf?sequence=1)

8. Idress, M. and M. Ibrahim. 1993. Agricultural Credit role in the Development of Agriculture. Journal of Rural Development and Administration 25(4): 64-74

9. Anka, A.M.L. 1992. Analytical Report on Supervised Agricultural Credit, its Problems Prospects and Suggestions for Implementation in Pakistan' Journal of Rural Development and Administration.24 (1):137147.

10. Arif, 2001. Effect of micro credit disbursed by ADBP on agricultural production in District Attock: Institute of Development Studies Faculty of Rural Social Sciences, KP, Agriculture University Peshawar, Pakistan.

11. Ashfaq, M. and Khan H.(2012). "Determinants of Credit off Take in Informal Credit Market.(A case study of village Regi District Mardan)"ThesisM.Phil(Economics). Institute of Development studies Faculty of Rural Social Sciences Agricultural University Peshawar-Pakistan.

12. Justin .K 2015. Factors influencing maize crop production at household levels: A case of Rukwa Region in the southern highlands of Tanzania Justin K. Urassa Development Studies Institute, Sokoine University of Agriculture, Morogoro, Tanzania.

13. Khan, S.A. 1981. Growth of Agricultural Credit Facilities in Pakistan. A Historical Review, in Agricultural Credit Pakistan's Experience Karachi: The institute of Bankers in Pakistan.

14. Khan, R.A. 1996. Some Success Stories of Poverty Alleviation Credit Program's in Asia' Journal of Rural Development and Administration. 1(28): 159-166.

15. Khan N. Jan I. Rehman M. Mehmood A. Ali A. 2007. The Effects of Short Term Agricultural Loans Scheme of Zari Taraqiati Bank on Increase in Farm Production in District Karak, Sarhad J. Agric, 23 (4): 1285-1290.

16. KP Development Statistics, 1997-98

17. Malik, S.J. 1989. Differential Access and the Rural Credit Market in Pakistan Some Recent Evidence. The Pakistan Development Review.28:4.

18. Malik, S.J. 1993. Agricultural Credit Markets for Sustained Growth and Development of Agriculture in Pakistan.

19. Matsumoto, T., and T. Yamano, 2010. "The Impact of Fertilizer Credit on Crop Production and Income in Ethiopoia". GRIPS Discussion Paper 10-23. National Institute for Policy Studies 7-22-1 Roppongi,Minatoku, Tokyo, Japan 106-8677. P.1.

20. Mbata, J.N. 1991. An Evaluation of institutional Credit and its Role in Agricultural Production in Rivers State, Nigeria, Savings and Development Supplement Vo.1:5-2.

21. Mohiuddin, Y. 1993. Credit Worthiness of Poor Women' Compassion of Some Mininalist Credit Program in Asia, A Preliminary Analysis. Pakistan Development Review-.pp. 1027-1199.

22. Javed S.M et al. 2006. "Impact Assessment of Micro-Credit Program of PRSP on Crops Productivity". Pak J. Agri. Sci. Vol.(43): 3-4.

23. Jehan, N., and M. Ahmad, 2008. "Raising of Productivity Through Agricultural Credit". (A Case study of Zari Tarqiati Bank of Pakistnan Limited). Sarhad J. Agric. Vol.24(4): 693-696

24. NTABAKIRABOSE, G. 2017. AN ECONOMIC ANALYSIS OF THE FACTORS INFLUENCING MAIZE PRODUCTIVITY AND EFFICIENCY IN RWANDA: A CASE STUDY OF MASTERS OF SCIENCE (Agricultural and Applied Economics) JOMO KENYATTA UNIVERSITY OF $\begin{array}{llll}\text { AGRICULTURE } & \text { AND } & \text { TECHNOLOGY }\end{array}$ (.(http://ir.jkuat.ac.ke/bitstream/handle/123456789/3480/Ntabakirabose2C\%20Gaspard\%20Agricultural\%20and\%20Applied\%20Economics$2017 \% 20$ mirror 1. pdf? sequence $=1 \&$ isAllowed $=\mathrm{y}$ 
25. Ochola S.A., and W. Kosura 2007. "Case study on Tobacco cultivation and possible alternative cropsKenya”. Institute for Natural Resources and Technology Studies(INRS) Page -23

26. Okoboi G., J. Muwanga and T. Mwebaze, 2012. "Use of Improved Inputs and Its effects on Maize yield and Profit in Uganda”College of Business and Management Science, Makeree University ,P.O.Box 702, Kampala, Uganda.Scholarly Peer Reviewed Vol.12 No.7.

27. Oladejo, J.A and Adentunji, M.O. 2012. Economic Analysis of maize (Zea mays. I) Production in Oyo state of Nigeria. Department of Agricultural Economics, Ladoke Akintola University of Technology, Ogbomosho, Oyo state, Nigeria. Agricultural Science Research Journals Vol.2(2): 77-83 (Available online $\mathrm{http} / / \mathrm{www} . \mathrm{resjournals.com/ARJ}$.

28. Ranum, P., J.Pablo, P.Rosas, M.Nieves, and G.Casa, 20141. Global maize production, utilization, and consumption. The New York Academy of Science

29. Syed I. 2012. "Role of Zari Tarqiati Bank Limited in Agricultural Productivity Through Agricultural Loan in Rural Areas of District Buner" Thesis M.Sc.(Hons) Rural Development, Institute of Development studies Faculty of Rural Social Sciences Agricultural University Peshawar-Pakistan.

30. Scheiterle L. and Birner, R., 2016. Comparative Advantage and Factors Affecting Maize production in Northern Ghana: A Policy Analysis Matrix StudyInvited paper presented at the 5th International Conference of the African Association of Agricultural Economists, September 23-26, 2016, Addis Ababa, Ethiopia

31. Tenaw S. and K.M.Z. Islam 2009. "Rural financial services and effects of microfinance on Management. Discussion Papers No.037.

32. World Leading Countries in Maize Production in the World (https://www.worldatlas.com/articles/worldleaders-in-corn-maize-production-by-country.html)24/11/2018

33. Zuberi, H.A. 1989. "Production Function, Institutional Credit and Agricultural Development in Pakistan" The Pakistan Development Review 28:1, 43-56. 